\title{
DISCURSO DE DESPEDIDA EGRESADOS DE DERECHO PRONUNCIADO POR EL PROFESOR SR. SERGIO GÓMEZ NÚNEZ
}

El vínculo que en suerte me ha correspondido con Uds. los alumnos que hoy egresan, es profundo e indeleble ya que ha sido continuo por los cinco años de sus estudios.

Es pues, para mi, una circunstancia afortunada tener esta oportunidad de compartir con Uds. estas reflexiones.

Cuando me plantee este propósito, encomendado por cierto, muchas cosas, de aquellas que me hubiera gustado escuchar, me alumbraron la senda de estas ideas. Pero una de las más recurrente fue la siguiente interrogante que surge del querer íntimo de los intereses que nos reune y es la de Ser abogado.

¿Qué es ser abogado?

Fíjense Uds. que esta afirmación está siempre precedida por el verbo "ser". No es una situación transitoria. Es de una permanencia, es decir, afirma del sujeto lo que significa el atributo.

Es un atributo. Atributo que modifica las cualidades del ser.

Es, pues eso, un atributo.

¡Y qué más importante atributo!

Ser abogado no es una simple declaración: es un ejercicio, es una praxis, es una forma de vida es, en fin, una suerte de apostolado.

Pero, en verdad, si bien es cierto que desde el punto de vista formal, uno es abogado cuando queda investido del título de tal por la Excma. Corte Suprema, no menos cierto es, que este atributo que modela al ser se va constituyendo lentamente, acaso ni siquiera se inicia con nuestros estudios en la Escuela de Derecho. No, su origen hay que buscarlo todavía más lejos.

Siempre habrá uno o más hechos, conscientes o no, que nos han conducido a esta profesión. Quizá si allá en la niñez existan recuerdos que nos tocaron profundamente y que nos hicieron sentir con incuestionable certeza que algo rompía el cristalino equilibrio de los que sentíamos por justo, como una piedra arrojada a una laguna altera el espejo en que se refleja el entorno.

Algo, quizá si una repulsa que con el paso del tiempo se va volviendo certeza en la madurez de la juventud.

Hay muchas y diferentes formas de acercamiento al ser abogado, pero hay una que constituye, en su origen, la esencia del ser abogado: la necesidad de la justicia. 
Justicia que es más fácil sentirla que definirla, pero que mora en su esencia en nuestros corazones.

Cuando ese sentimiento se ha entronizado en nosotros, surge inevitablemente la necesidad de darle cauce. Ese cauce constituye, desde el punto de vista formal, las escuelas de Derecho.

La Escuela de Derecho, constituye el verdadero crisol de la formación del abogado, en que, generalmente, otros abogados (de mayor experiencia) traspasan ésta a sus alumnos.

Pero en ello no sólo va involucrado el estudio coherente, por materias, profundizado o generalizado, o como se llame, va algo más que eso, van nuestras experiencias, percepciones, meditaciones, dudas y frustraciones, va, en fin, una suerte de caleidoscopio que constituye una aproximación al ser abogado.

Todo este estudio presencial dura aproximadamente cinco años -aunque algunos hacen uso de la libertad que les otorga la Universidad para sumarle algunos años adicionales-. Esta es la etapa que Uds. ya han cumplido.

Resta la elaboración de una tesis y el examen de grado par obtener el título de licenciado en Ciencias Jurídicas y Sociales. Luego de una práctica profesional estarán habilitados para recibir el ansiado título de abogado de la Excma. Corte Suprema. Unico título de carácter universitario que no entrega la Universidad en Chile.

De esta manera ya habremos cumplido con las formas. $Y$, entonces, formalmente seremos abogados.

En verdad, y en estricto rigor, y esta es mi experiencia, cuando llegó ese momento: cuando recibí mi título, sentí algo parecido a ser abogado, pero en verdad no estuve seguro de ello hasta mucho tiempo después.

\section{¿Y por qué este sentimiento?}

Pues, precisamente, por lo que venimos comentando, porque los atributos del ser se estacionan en él después de algún tiempo. Porque ser abogado no es una situación estática. No. Es absolutamente dinámica.

Ser abogado, es construirse diariamente, es estudiar, investigar, es aprender, es meditar, es, en fin, un tratar de ser.

Ser abogado, no es simplemente ejercer la profesión, en cualquier campo, con lo que ya aprendimos. un deber.

Ser abogado es una diario aprendizaje, es un estudio renovado, es una lucha, es

Para ello debemos ser inquietos, inquietos intelectualmente: que todo nos asombre, que todo nos importe. Es quizá ésta la más relevante de las enseñanzas.

Pero, sin duda alguna, la perseverancia constituye el instrumento fundamental del quehacer del abogado. Perseverancia en los principios, en el trabajo, en nuestras obligaciones y propósitos. 


\section{Sergio Gómez Núñez}

Todo ello nos permitirá que llegue ese momento mágico en que nos sintamos realmente abogados, y digamos con una profunda satisfacción, con fuerte orgullo: soy abogado.

Les confieso: en mi vida tengo muchos motivos para sentirme muy orgulloso, pero uno de los cuales más me enorgullece es poder decir, porque lo siento, es que soy Abogado.

Querido alumnos que hoy comienzan su alejamiento presencial de esta Escuela de Derecho, en la vida profesional van a encontrar muchos, pero muchos, obstáculos que los harán renegar de muchas cosas, pero también habrá muchos y muchos otros por los cuales sentirse satisfechos.

Pero el ejercicio de la profesión de abogado, procuren llevarla como una parte de su ser, que ejercida con dignidad, con respeto, con sentido de justicia y con profunda honestidad, les haga decir, también conmigo y con mucho, mucho orgullo: soy abogado.

Mis deseos de éxito para Uds. 